\title{
Unravelling The Global City Debate on Social Inequality A Firm Level Analysis of Wage Inequality in Amsterdam and Rotterdam
}

\author{
Jack Burgers \& Jeroen van der Waal
}

\section{Local consequences of globalization: upgrading or polarization?}

In both the academic and political debate on globalization, inequality is undoubtedly the most disputed theme (cf. Dicken, 2003; Held \& McGrew, 2000). This is also true in the field of urban studies, especially in the debate on global cities, where much attention has been paid to the local social effects of globalization. Two opposing views have been brought forward. One states that the globalization of urban economies results in increasing local inequality and even social polarization (cf. Sassen, 1991, 2001; Friedmann \& Wolff, 1982; Friedmann, 1986). The other states that globalization of urban economies leads to an upgrading of metropolitan labor-markets (cf. Hamnett, 1994; 1996; Waldinger, 1996). The debate on this issue has been going on for some time now and is still not brought to a conclusion. Empirical data has been presented that, allegedly, corroborates either one of both theoretical positions. This paper is based on the argument that the main reason for this empirical deadlock is the result of interrelated theoretical and operational ambiguities.

The first ambiguity concerns the role of international competition. In the economic literature on globalization, in which countries and not cities are the units of analysis, the dominant argument is that globalization leads to upgrading labor-markets in the advanced economies (Dicken, 2003). The main line of reasoning here is that in order to maintain their competitive edge, advanced economies have to cut on labor costs by automation or else increase the quality of their products. Either way, globalization - in the sense of increasing international economic exposure - leads to upgrading national labor-markets. This is in line with what some authors have argued as to how urban labor-markets are developing (Hamnett, 1994; 1996; Waldinger, 1996). But global cities might be an exception here because one of the key characteristics of global cities is that global cities do not compete so much with other cities but, rather, form a limited set of strategically cooperating cities (Sassen, 1991; 2001). So, at least theoretically, polarization in global cities is not necessarily incompatible with the general argument of increasing international competition leading to upgrading labor-markets. Before assessing social inequality, one should therefore analyze the international exposure of urban economies. The second ambiguity concerns the conceptualization of the global character of an urban economy. In many cases - prominently so in the work of Sassen $(1991,2001)-$ globalization is operationally conceived of as, or at least directly related to 'economic restructuring': the increasing employment in services and the decreasing employment in manufacturing industries. For global cities, economic restructuring to a large degree may 
be the result of their specific role in the world economy. But there is a broad consensus that economic restructuring in general is not caused by globalization but, rather, by changes in (national) demand and technological developments (cf. Krugman, 1994; 1996; Krugman \& Lawrence, 1994). Therefore, one should differentiate between globalization and economic restructuring instead of equating them in order to assess the local effects of globalization. Potentially at least, they have different effects. The third ambiguity relates to the question of agency. The globalization of urban economies is not brought about by cities so much, but by the firms and enterprises settled there (cf. Taylor, 2004). In other words, when it comes to globalization, one should analyze firms and companies, not cities as such. Studying urban labor-markets in general means that one does not differentiate between global and non-global economic activities. Even in global cities, there are substantial parts of the urban economy that are not internationally operating or orientated. As Sassen (2006b: x) has argued, the "...global city is not a descriptive term meant to capture a whole city". By using employers and firms as units of analysis one can differentiate between global and non-global economic activities. By doing so, one can directly relate the international character and involvement of different forms of employment to the consequences for social inequality in terms of wage-levels.

Using data on the Dutch cities of Amsterdam and Rotterdam we will assess the local effects of globalization on social equality. We will do so by using data on social inequality collected at the appropriate level, i.e. firms and employers and not cities in general. We distinguish between a global city (Amsterdam) and a non-global city (Rotterdam). We will analyze and differentiate between the effects of global city formation, international exposure and economic restructuring on social inequality. In section 2 we will derive eight propositions from the discussion on the global city thesis that will guide us through our analyses on firms and employers in Amsterdam and Rotterdam. In section 3, we describe the dataset we used and test our hypotheses by means of multiple regression analyses. Section 4 concludes with our main findings and suggestions for further research.

\section{Globalization and Urban Inequality: Eight Basic Propositions}

Global cities have been conceived of as part of a new geography, related to the most recent phase in the internationalization of the economy (Sassen, 2000; 2001; 2006a). According to global city theory, the international division of labor is a process of centralized decentralization, where global cities are the organizing centers. Basically, global cities form a web spun by the headquarters of transnational corporations situated there. In this web, global cities complement each other and, paradoxically, do not suffer from the global competition they themselves induce. Worldwide, there are 'about forty' of those global cities (Sassen, 2006a: 315). Besides empirically mapping worldwide hierarchies of cities, research addressing the global city thesis has particularly focused on the issue of social polarization, as we stated before.

In global city theory, social polarization is related to the specific coordinating economic role of those cities. The main economic force in global cities is a limited number of 
rapidly growing sectors, more specifically corporate headquarters, but also advanced producer services such as international finance, accountancy and law firms, and the consumer functions that cater to the highly skilled knowledge workers in those cities. In general, the service sector has both a higher share of low-income and high-income employees than the traditional manufacturing sector. Contrary to the industrial era in which historically the share of middle-income employees has been constantly expanding, global city theory predicts a growing share of both low-income and high-income employees and therefore can be conceived of as 'the theory of the declining middle'.

In the actual practice of empirical research on the issue of polarization, the concept of the global city has in many cases been used as a heuristic category in the sense that the global city serves as a model that is tested in research on inequality in cities in general. Sassen, the very founder of the concept, herself has contributed to the confusion as to the status of the concept of the global city as either an essentialist 'thing' - which is suggested by her claim that there are 'about 40' global cities (Sassen, 2006a: 315) - or the global city as a heuristic "device': “... an analytical construct [our italics, JB/JvdW] that allows one to detect the global as it is filtered through the specifics of a place...." (Sassen, 2006b: $\mathrm{x}$ ). This is an important distinction because by using the global city as a heuristic concept which, we would argue, is the regular practice in the field of urban studies - one loses track of the effect of international competition on social inequality. This is highly problematic, because international competition is a key variable in the economic literature on globalization and wage inequality. The main argument here is that increasing international competition leads to an upgrading of the job and wage structure in advanced economies. An increasingly knowledge-based and technologically innovative production, needed to stay ahead of low-wage countries, is seen as the main cause of this upgrading (Dicken, 2003). Hence if, as global city theory claims, global cities form a distinct set of basically not competing but, rather, strategically collaborating cities, their social structure may not be paradigmatic for other, i.e. non-global, cities that experience international competition - as most cities do. As a consequence, global cities may have a social structure that is different from non-global cities (polarizing vs. upgrading labor-markets, respectively). This means that, in assessing the urban social consequences of globalization, it is essential to differentiate between global and non-global cities instead of using global city theory as a paradigm for cities in general.

Although Sassen (2001: 350, 351) specifically has argued that global city functions do not comprise all economic activity in global cities, research nonetheless tends to addresses all jobs in cities (see for this research practice, inter alia Baum, 1997; Baum, 1999; Hamnett, 1994; Hamnett, 1996; Tai, 2006; Walks, 2001). This is not surprising because the logic of global city theory of how polarization exactly comes about focuses, as we stated before, on characteristics of the emerging service economy. Commercial services are especially characterized by both high and low-income jobs, and these services are important and maybe even decisive in terms of what makes a city a global city. In Sassen's analysis, much of what she has to say about the labor-market characteristics of global cities is essentially derived from the service character of those cities. But the point is that the transition from a manufacturing or industrial economy to a service economy is a general phenomenon in advanced economies and not restricted to 
global cities. Although economic restructurering in global cities to a large extent may indeed be induced by their coordinating role in the world economy - the headquarters of transnational corporations situated there and all the services catering to these corporations and their highly skilled and highly paid professional workers - economic restructurering outside global cities cannot be explained by globalization, but is mainly brought about by technological innovation and changing national demand, as we stated before (cf.

Krugman, 1994; 1996; Krugman \& Lawrence, 1994). So, if economic restructuring would only cause polarization in global cities, this then could be entirely ascribed to globalization. However, if both global and non-global cities would experience polarizing tendencies because of economic restructuring, globalization cannot be the explanation of this phenomenon. So, comparing the social consequences of economic restructuring in a global city to that in a non-global city can shed light on this matter.

The only way to distinguish empirically between international exposure and economic restructuring in terms of their effects on social inequality is to analyze firms and employers in cities instead of urban labor-markets in general. Only at that level is one able to differentiate between international exposure and the sectorial structure of an urban economy. Doing so, one solves an important general problem of global city theory: that of the agency of global cities.

In a convincing critique of the major formulations of the global city thesis, Taylor (2004) has argued that most assertions about the nature and social makeup of global cities at closer scrutiny are not really empirically substantiated - Short et al's (1996) 'dirty little secret' of the theory on global cities. Most of the data used in the important theoretical statements are, at best, illustrations rather than empirical proof of the global city thesis because the data used does not really relate to the central concepts. According to Taylor (2004), cities become part of international networks through the agency of the corporations located in those cities. We not only firmly agree with Taylor's line of reasoning, but want to carry his argument even one step further and argue that if one aims at assessing the social consequences of globalization one should assess firms and employers and not cities.

Recapturing our arguments thus far, we can formulate eight rather straightforward propositions, which, taken together, not only unravel the complicated theoretical arguments in global city theory, but also can also decide the debate on globalization and urban inequality:

1) Global cities experience less international competition than non-global cities;

2) This is caused by their different sectorial composition in comparison to nonglobal cities. Steering the global economy and facilitating that process leads to a disproportionate share of commercial services in global cities.

3) Due to these steering and facilitating functions, commercial services in global cities experience less international competition than commercial services in non-global cities.

4) Global cities have a more polarized wage-structure than non-global cities. In non-global cities, exposed to international competition as they are, one finds upgrading tendencies. 
5) The polarized wage structure in global cities is caused by the greater share of commercial services compared to non-global cities.

6) And by a more polarized wage structure of the commercial services in global cities in comparison to those in non-global cities. Commercial services in global cities comprise first and foremost their global functions and the functions that facilitate them.

7) Since non-global cities are exposed to international competition, they experience upgrading tendencies. The polarized wage structure of global cities comprises a large share of low-income employees. Therefore non-global cities should have a relatively upgraded wage-structure in comparison to global cities.

8) This relatively upgraded wage-structure in non-global cities is caused by exposure to international competition.

We will put these propositions to the test by looking at the two main cities of the Netherlands, Amsterdam and Rotterdam. Both cities are within the same institutional context of the Dutch welfare-state and therefore we control for differences between welfare-state regimes, which is an important variable as it comes to (urban) wage inequality (cf. Burgers \& Musterd, 2002; Vaattovaara \& Kortteinen, 2003). In our analysis, we will use Amsterdam as a global city and Rotterdam as a non-global city - or at least Amsterdam being much closer to the ideal/typical global city than Rotterdam. In fact, Amsterdam has been qualified as a global city by the very founder of the concept (Sassen, 1991; 2000; 2001; 2006a), and has been labeled a 'gamma world city' - indicating a high world city status - by Taylor (2004), because of the high intercity connectivity of its advanced producer services. Rotterdam, on the other hand, has never been mentioned as a part of the web of global cities, and scores much lower on the inter-city connectivity of its advanced producer services than Amsterdam $-75^{\text {th }}$ on a world scale compared to $12^{\text {th }}$ for Amsterdam (Taylor, 2004). Clearly, only Amsterdam belongs to one of the 'about forty' cities Sassen labeled as 'global' in her most recent study (2006a: 315).

By using data on employers - see next section - based in Amsterdam and Rotterdam we overcome the problem of agency that, as we have seen, is so central in much global city research. Our data makes it possible to assess international competition instead of assuming it, and they allow for disentangling the effects of international exposure and economic restructurering on social inequality.

\section{Data \& Operationalization}

Our analyses are based on the Dutch biannual 'OSA-labour demand panel' which started in 1989. The OSA Employers' survey is designed to allow more insight into the nature and size of demand for labor by organizations, as well as more particular factors concerning the demand for labor at establishment level. The organizations are asked for detailed information concerning their product, production processes, the technologies used, their personnel, personnel policy and diverse financial and economic indicators. ${ }^{\mathrm{i}}$ 
The panel consists of a random sample survey of companies with more than five employees.

Data are gathered by written questionnaires and interviews, both face-to-face and by telephone. Because many companies drop out every new round of data collection, in every 'wave' new companies are randomly selected to complete the sample.

We will only use data of companies settled in the agglomerations of Amsterdam and Rotterdam. ${ }^{\text {ii }}$ In order to get a substantial number of cases within those urban regions, we used five different waves of data collection - 1995, 1997, 1999, 2001 and 2003 - and combined them to one dataset. In doing so, we maximize the number of companies, without including companies more than once. ${ }^{\text {iii }}$

Dependent variables ${ }^{i v}$ - in order to rank companies in terms of to what degree they are part of the international economy we used two variables. The first is the percentage of returns realized by exports. The second is a dichotomy, indicating whether companies experience foreign competition or not. These two variables are standardized and as such combined in a new variable international exposure ${ }^{v}$ : a scale indicating the average score on the two constituting variables.

In each volume of the survey, companies were asked for the percentage of employees per income category. Each volume used either seven or eight income categories. The lowest income category is used for the variable percentage of low-income employees. ${ }^{\text {i }}$

The construction of the variable polarization needs some elaboration. The notion of polarization has been defined as the thesis of 'the declining middle': the middle-income stratum gets smaller while the low-income and high-income stratums both increase.. If they would not both increase, it would either be a case of upgrading - the high-income stratum grows while the low-income stratum does not - or downgrading - the lowincome stratum grows while the high-income stratum does not. To measure polarization we used the mean pair distant coefficient. ${ }^{\text {vii }}$ This coefficient is able to measure income inequality in the form of pure polarization, that is leaving upgrading and downgrading out, which most measures of inequality fail to do. As such, it is the best indicator for testing the theory of the declining middle.

Independent variables - to compare Amsterdam and Rotterdam, we created a dummy variable city dummy coding Amsterdam as 1 and Rotterdam as 2. For the assessment of the consequences of the differing sectorial composition of, and the differing composition of sectors between, these cities we constructed economic sector dummies: Industry, Commercial services and Non-commercial services. The social consequences of international exposure will be assessed by using the variable international exposure as described above.

Control variables - we will use year as control variable because, as stated above, the data contain volumes of different years, while most of the time we do not measure the effect of the course of time. We also use company size - the number of employees - as a control variable. The categories '5-10', '10-20', '20-50', '50-100', '100-500' and 'more than 500 employees' have been recoded from 1 trough 6 respectively. The open character of the last category and the large range of the last, but one, category made us decide to 'reduce' this variable to a quasi interval level, instead of assuming means for each category. 


\section{Globalization and Urban Inequality: Testing the Propositions}

First, we check whether Amsterdam and Rotterdam do differ in the extent to which their companies are exposed to the international economy. In order to do so, we regressed the city dummy on international exposure (model 1, table 1). The coefficient of the city dummy is positive and significant. Since Amsterdam is coded as one, and Rotterdam is coded as two, this means - consistent with the global city-theory - companies in Rotterdam are more exposed to the international economy than companies in Amsterdam, confirming hypothesis 1 .

According to the global city-theory, the difference in exposure to international competition between Amsterdam and Rotterdam's companies should be the result of a difference in the sectorial composition of their economies. To assess this assumption we entered dummies for the manufacturing industrial sector and the commercial services

Table 1: Regression analyses. Dependent variable is international exposure. (Method: Ordinary Least Squares).

\begin{tabular}{|c|c|c|c|}
\hline & Model 1 & Model 2 & Model 3 \\
\hline \multicolumn{4}{|l|}{ Independent variables } \\
\hline & $\boldsymbol{\beta}$ & B & $\boldsymbol{\beta}$ \\
\hline City dummy (Rotterdam) & $0.067 *$ & 0.047 & 0.049 \\
\hline Manufacturing & & $0.352 * * *$ & $0.347 * * *$ \\
\hline Commercial services & & $0.316 * * *$ & $0.318 * * *$ \\
\hline Non commercial services (ref.) & & 0 & 0 \\
\hline Industry x Rotterdam & & & $0.059 *$ \\
\hline Commercial services x Rotterdam & & & 0.034 \\
\hline \multicolumn{4}{|l|}{ Control } \\
\hline Company size & $0.158 * * *$ & $0.189 * * *$ & $0.190 * * *$ \\
\hline $\mathrm{R}^{2}$ & 0.030 & 0.141 & 0.142 \\
\hline $\mathrm{N}$ & 1305 & 1305 & 1305 \\
\hline
\end{tabular}

sector in the analysis (model 2) - the non-commercial services are the reference category. Both coefficients are positive and significant - the coefficient of manufacturing industries being the stronger one. Since the reference category is non-commercial services this is no surprise: non-commercial services are not directly internationally exposed. More important, the coefficient of the city dummy is smaller than in model 1, and has become statistically insignificant, meaning that the higher exposure to the international economy of Rotterdam's companies can partly be explained by the different sectorial makeup of Amsterdam and Rotterdam's economies - confirming hypothesis 2. Since the coefficient of the city dummy has become insignificant in model 2, assessing whether the difference in exposure to the international economy between Amsterdam and Rotterdam business is partly caused by the different make-up of the same sectors between these cities as argued in the 'global city'-theory (hypothesis 3), is not possible anymore. What can be assessed however is whether sectors indeed differ between cities when it 
comes to exposure to the international economy. Therefore we entered interaction effects of the sector dummies with the city dummy (model 3). Both interaction effects are positive as expected. Only the interaction effect with the industrial sector is significant: companies in the industrial sector in Rotterdam are more exposed to the international economy than those in Amsterdam. Although expected, this is not the case for companies in the service sector.

In sum, global city-theory proves to be correct when it comes to the relative absence of exposure to international competition in global cities. Global city Amsterdam's economy is less exposed to international competition than Rotterdam's economy. Consistent with global city-theory, this is caused by the different economic structure of the two cities. This leads to the important conclusion that the use of global city-theory for the assessment of the social consequences of globalization in cities in general creates a blind spot for the social consequences of international competition. Although international competition is extensively theorized in globalization literature at large, it is relatively absent in much of the urban studies literature because it does not fit in global city-theory which, as we argued before, has dominated if not monopolized empirical research on the social consequences of globalization. Essentially, the dominance of global city-arguments in research on social inequality in contemporary cities has led to a tunnel vision in which the social consequences of international competition have been neglected. Since international competition is a core feature of economic globalization, we would argue this underassessment is not only hard to justify but, more seriously, may have led to a distorted view of the consequences of globalization for most cities' economies and thus the fortunes of their inhabitants.

Because the social consequences expected to be caused by global city-formation on the one hand and international competition on the other differ, recognizing and assessing the multidimensionality of globalization is all the more important. Global city formation is expected to cause polarizing tendencies whereas increasing international competition is expected to cause upgrading.

An assessment of the social consequences of globalization in western cities should therefore not only be aware of the way cities are integrated into the global economy being 'global' or 'non-global' - and the multidimensional character of economic globalization, but also of resulting different social consequences thereof about to be assessed.

First we checked whether business in Amsterdam differs from that in Rotterdam when it comes to the extent of polarization of the income structure (table 2, model 1). Since the coefficient of the city dummy is negative and significant, companies in Amsterdam prove to have a more polarized income structure that those in Rotterdam, confirming hypothesis 4. In model 2 we entered the sector dummies to assess whether the differing sector distribution is responsible for this difference. In line with global citi- theory, companies in the commercial services have a more polarized income structure than those in manufacturing. However, this proves not to be the reason of the more polarized income structure in Amsterdam's companies since the coefficient of the city dummy declines only marginally. Therefore, hypothesis 5 has to be rejected. 
Table 2: Regression analyses. Dependent variable is polarization in income distribution. (Method: Ordinary Least Squares).

\begin{tabular}{lllc}
\hline & Model 1 & Model 2 & Model 3 \\
\hline Independent variables & $\boldsymbol{\beta}$ & $\boldsymbol{\beta}$ & $\boldsymbol{\beta}$ \\
City dummy (Rotterdam) & $-0.068^{*}$ & $-0.065^{*}$ & $-0.072^{*}$ \\
Manufacturing (ref.) & & 0 & 0 \\
Commercial services & & $0.084^{*}$ & $0.086^{*}$ \\
Non commercial services & & $-0.121^{* *}$ & $-0.117^{* *}$ \\
International exposure & & -0.045 & -0.047 \\
Commercial services X City dummy & & -0.010 \\
Non commercial services X City dummy & & & -0.055 \\
Control variables & & & \\
Year & $-0.069 *$ & -0.057 & -0.059 \\
Company size & -0.052 & -0.030 & -0.029 \\
$\mathrm{R}^{2}$ & & & \\
$\mathrm{~N}$ & 0.006 & 0.033 & 0.045 \\
\hline p $<0.1 * * \mathrm{p}<0.05 ; * * * \mathrm{p}<0.01 ; * * * \mathrm{p}<0.001$ & 612 & 612 & 612 \\
\hline An & & & \\
\hline
\end{tabular}

Analyses of the OSA labour demand panels 1995, 1997, 1999, 2001 and 2003 with companies based in the COROP-areas Amsterdam en Rotterdam.

In the last model (3) we entered the interaction effects of the sector dummies with the city dummy. Both prove to have insignificant $\beta$-coefficients leading to the rejection of hypothesis 6 . Contrary to what one should expect because of their supposed global city functions, Amsterdam's commercial services do not have a more polarized income structure than those in Rotterdam.

Summing up, firms in Amsterdam - the global city in our analytical framework - indeed show a more polarized income structure that those in Rotterdam. However, 'global city' arguments paradoxically prove not to be the cause for these polarizing tendencies, since hypotheses 5 and 6 have been rejected. Only deindustrialization - the decrease of employment in manufacturing industries - leads to polarizing tendencies since companies in the commercial services sector have a more polarized income structure than companies in the industry sector. Since this goes for both Amsterdam and Rotterdam, it cannot explain the more polarized income structure of Amsterdam's firms and therefore another explanation has to be found.

In the first model in table 3 we checked whether business in the city under scrutiny that is exposed to international competition most - Rotterdam - has the lowest share of lowincome

Table 3: Regression analyses. Dependent variable is percentage of low-income employees. (Method: Ordinary Least Squares).

\begin{tabular}{lll} 
Ordinary Least Squares). & Model 1 & Model 2 \\
\hline
\end{tabular}

Independent variables

$\beta$ 
City dummy (Rotterdam)

Industry (ref.)

0

$0.086^{*}$

Commercial services

$-0.128 * *$

Non commercial services

$-0.135^{* * *}$

Control variables

Year

$-0.024 \quad-0.017$

Company size

$-0.262 * * * *$

$-0.224 * * * *$

$\mathrm{R}^{2}$

0.068

0.105

612

$* \mathrm{p}<0.1 * * \mathrm{p}<0.05 ; * * * \mathrm{p}<0.01 ; * * * * \mathrm{p}<0.001$

Analyses of the OSA labour demand panels 1995, 1997, 1999, 2001 and 2003 with companies based in the COROP-areas Amsterdam en Rotterdam.

employees, as one should expect according to the upgrading logic. The $\beta$-coefficient of the city dummy in model 1 shows this is not the case. Since it is both positive and significant, there are more - not less - low-income employees in Rotterdam business, despite its higher exposure to international competition and the more polarized income structure of Amsterdam, falsifying hypotheses 7 and 8.

Although the last hypothesis cannot be corroborated anymore, we still entered international exposure and the sector dummies into model 2, to assess their consequences for the share of low-income employees within companies and the difference in this share between Amsterdam and Rotterdam. Model 3 shows that international exposure indeed leads to a lower share of low-income employees within companies, and that companies in commercial services have a higher share of low-income employees than those in the manufacturing industries. This last finding is not surprising either, since we have seen that companies in the commercial services sector are more polarized than those in the manufacturing industries and therefore have a higher share of low-income employees. The $\beta$-coefficient of the city dummy increases in strength: controlled for the higher exposure to the international economy, Rotterdam's business has an even higher level of low-income employees.

\section{Conclusions and Discussion: Global Versus Local Impacts on Social Inequality}

Our analyses of the relevant actors - firms and employers in cities - show that where it comes to international exposure, Amsterdam indeed may be qualified as a global city: compared to Rotterdam, Amsterdam's firms experience a relatively low degree of international competition. Also in line with global city-theory is the fact that Amsterdam's firms show a more polarized wage structure than those in Rotterdam. However, there is a theoretical problem here because the reasons suggested by global city-theory to bring this difference about, actually fail to do so. Neither the different sectorial make-up of the two cities, nor the different functions (global vs. non-global) of their economies explain the relatively polarized wage structure of Amsterdam compared 
to Rotterdam. This means that it is essential to test instead of illustrate theoretical statements on the urban social consequences of globalization (cf. Short et al., 1996). Besides, it is not so much global city formation that leads to polarizing tendencies, but economic restructuring in general since Amsterdam and Rotterdam do not differ in this respect.

Exposure to international competition leads to upgrading tendencies that are stronger than the polarizing tendencies induced by economic restructuring (compare table 2 and 3 ). Furthermore, the growth of non-commercial services - part of the process of economic restructurering - leads to depolarizing tendencies which are stronger than the polarizing tendencies of the growing service sector in general (table 2). In the global age noncommercial local services form a growing share in the economy of both global and nonglobal cities in the advanced economies (cf. Persky \& Wiewel, 1994). These services are part of the institutional make up of national welfare states, and are not related to globalization. In short, globalization's strongest effects on urban wage inequality are the upgrading tendencies due to international competition, while polarizing tendencies prove to be only partly caused by globalization - the growth of the service sector in a global city - and are at least partly cancelled out by the growth of the non-commercial services. We would argue that these findings seriously undermine the globalization-polarization nexus so dominant in urban studies.

But there is another factor of importance resulting from our analyses. If economic restructuring and increasing exposure to international competition would be decisive in explaining differences between Amsterdam and Rotterdam one would expect less lowincome workers in Rotterdam than in Amsterdam. But exactly the opposite is true. Most probably, the explanation is to be found in the supply-side of the labor-market: the Rotterdam labor-force on the average is less educated than the Amsterdam labor-force, as Table 4 clearly shows. Where in Amsterdam - and the other main Dutch cities for that matter $^{\text {viii }}$ - highly skilled jobholders outnumber workers with only basic schooling, in Rotterdam the opposite is true.

Table 4. Educational level Amsterdam and Rotterdam labour force.

\begin{tabular}{|c|c|c|c|c|}
\hline & Basic training & $\begin{array}{l}\text { Academic or } \\
\text { professional } \\
\text { training }\end{array}$ & Difference & $\begin{array}{l}\text { Ratio } \\
\text { Basic/Academic } \\
\text { or professional }\end{array}$ \\
\hline \multicolumn{5}{|l|}{ Amsterdam } \\
\hline 1996 & 99,000 & 164,000 & $+65,000$ & 0,60 \\
\hline 2002 & 101,000 & 202,000 & $+101,000$ & 0,50 \\
\hline \multicolumn{5}{|l|}{ Rotterdam } \\
\hline 1996 & 119,000 & 91,000 & $-28,000$ & 1,31 \\
\hline 2002 & 135,000 & 115,000 & $-20,000$ & 1,17 \\
\hline
\end{tabular}

Source: Statistics Netherlands

Again, one could argue that non-global processes are more important for urban wage inequality than the globalization of the economy.

Our corroboration of the argument that global cities, because of their steering and controlling role in the global economy, are not competing as much as other non-globalcities, implies that using global city theory as a heuristic device for analyzing the 
consequences of globalization in cities in general, maybe confusing if not outright obscuring (cf. McCann, 2004 for a similar argumentation concerning non-social issues). By definition, most cities are non-global cities and therefore it makes no sense analyzing their socio-economic structure on the basis of global city-arguments. Global city-theory sheds no light on those cities, nor can their socio-economic characteristics ever falsify global city-theory. Using global city-theory as a model for the analysis of local consequences of globalization tout court, leads to a blind spot for the social consequences of the increasing exposure to international competition. This, while international competition is not only considered to be one of the core features of globalization, but, as shown by our analyses, has a stronger impact on wage inequality than global city formation.

Furthermore, while using the global city concept as a heuristic device, economic restructuring is often seen as induced by or even as a proxy of globalization. Subsequently, many studies on the consequences of globalization in actual fact assess the consequences of deindustrialization (cf. inter alia: Baum, 1997; Baum, 1999 Tai, 2006; Walks, 2001). Analyzing the social consequences of globalization in cities based on global city theory is therefore not only obscuring a core feature of globalization as international competition, but also overstates the social consequences of globalization for many workers in cities in the advanced economies. After all, as argued before, economic restructuring in cities with the advanced economies is largely driven by local and national processes instead of international or global ones. Our findings indicate that even in the global age, local geographical, institutional and historical idiosyncrasies of individual cities seem to be decisive in understanding their socio-economic structure (cf. Smith, 2001).

\section{Literature}

Baum, S. (1997). Sydney, Australia: A Global City? Testing the Social Polarisation Thesis. Urban Studies, 34(11), 1881-1901.

Baum, S. (1999). Social Transformations in the Global City: Singapore. Urban Studies, 36(7), 1095-1117.

Burgers, J., \& Musterd, S. (2002). Understanding Urban Inequality: A Model Based on Existing Theories and an Empirical Illustration. International Journal of Urban and Regional Research, 26(2), 403-413.

Dicken, P. (2003). Global Shift: Reshaping the global economic map in the 21 st century (4 ed.). New York: The Guilford Press.

Hamnett, C. (1994). Social Polarisation in global cities: Theory and evidence. Urban Studies, 31(3), 401-425.

Hamnett, C. (1996). Social Polarisation, Economic Restructuring and Welfare State Regimes. Urban Studies, 33(8), 1407-1430.

Held, D., \& McGrew, A. (Eds.). (2000). The Global Transformations Reader: An Introduction to the Globalization Debate. Cambridge: Polity Press. 
Krugman, P. R. (1994). Peddling prosperity: economic sense and nonsense in the age of diminished expectations. New York: Norton.

Krugman, P. R. (1996). Pop internationalism (2nd print ed.). Cambridge, Mass.: The MIT Press.

Krugman, P. R., \& Lawrence, R. Z. (1994). Trade, jobs and wages, Scientific American, 270, 44-49.

McCann, E. J. (2004). Urban Political Economy Beyond the 'Global City'. Urban Studies, 41(12), 2315-2333.

Persky, J., \& Wiewel, W. (1994). The growing localness of the global city, Economic Geography (Vol. 70, pp. 129).

Sassen, S. (2000). Cities in a World Economy (2 ed.). London: Pine Forge Press.

Sassen, S. (2001). The global city: New York, London, Tokyo (2 ed.). Princeton: Princeton University Press.

Sassen, S. (2006a). Territory, authority, rights: from medieval to global assemblages. Princeton: Princeton University Press.

Sassen, S. (2006b). Foreword: Searching for the global in the urban. In M. M. Amen, K. Archer \& M. M. Bosman (Eds.), Relocating Global Cities: From the Center to the Margins (pp. ix-xiii). Lanham: Rowman \& Littlefield Publishers.

Short, J. R., Yeung, K., Kuus, M., \& Wells, H. (1996). The Dirty Little Secret of World Cities Research. International Journal of Urban and Regional Research, 20, 697717.

Smith, M. P. (2001). Transnational Urbanism: Locating Globalization. Oxford: Blackwell.

Tai, P.-F. (2006). Social polarisation: Comparing Singapore, Hong Kong and Taipei. Urban Studies, 43(10), 1737-1756.

Taylor, P. J. (2004). World City Network: A Global Urban Analysis. London / New York: Routledge.

Vaattovaara, M., \& Kortteinen, M. (2003). Beyond Polarisation versus Professionalisation? A Case Study of the Development of the Helsinki Region, Finland. Urban Studies, 40(11), 2127-2145.

Walks, A. R. (2001). The Social Ecology of the Post-Fordist/Global City? Economic Restructuring and Socio-spatial Polarisation in the Toronto Urban Region. Urban Studies, 38(3), 407-447.

Waldinger, R. (1996). Still the Promised City? African-Americans and new Immigrants in Postindustrial New York. Cambridge: Harvard University Press.

Wessel, T. (2005). Industrial Shift, Skill Mismatch and Income Inequality: A Decomposition Analysis of Changing Distributions in the Oslo Region. Urban Studies, 42(9), 1549-1568.

Notes

\footnotetext{
${ }^{\mathrm{i}}$ For more information see: http://www.tilburguniversity.nl/osa/datasets/labour_demand_panel.html.

ii More specifically, we use the so-called 'COROP-area', which is an urban area based on a nodal classification principle. Each COROP-area has a central core (city) with a surrounding area measured by relations such as the traffic between place of residence and place of work of urban employees.

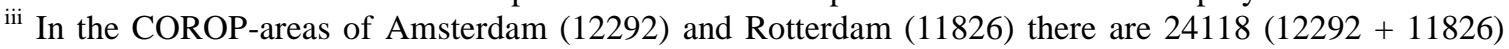
companies with five or more employees (point of meausurement 01-01-2005). This means you have to have a sample size of at least 378 for a confidence interval of $5 \%$ and a confidence level of $95 \%$ for your
} 
analyses. This proves to be no obstacle for the anayses in this chapter. Calculated on: http://www.surveysystem.com/sscalc.htm at 25-10-2006.

${ }^{\text {iv }}$ All variables in the analyses have been standardized.

${ }^{v}$ A principal component analysis on these two standardized variables gives a first factor that explains $74 \%$ of the variance. The factor loadings of these variables are both 0,864. A reliability analysis gives Cronbach's Alpha of 0,655. This indicates a reasonable scale.

${ }^{\text {vi }}$ It needs to be emphasized that the volumes do not always use the same category limits. To overcome possible invalid research findings because of this we will use year as a control variable (see below).

vii The polarisation index - a mean pair distant coefficient - is calculated as follows:

polarisation index $=((((\mathrm{hwc} * 1 \mathrm{wc} *(\mathrm{ABS}(1-3))+((\mathrm{hwc} * \mathrm{mwc} *(\mathrm{ABS} 1-2))+((\mathrm{mwc} * \mathrm{hwc} *(\mathrm{ABS}(2-1))+$ $\left(\left(\mathrm{mwc} * 1 \mathrm{wc} *(\mathrm{ABS}(2-3))+\left(\left(\mathrm{hwc} * \mathrm{lwc} *(\mathrm{ABS}(3-1))+\left(\mathrm{wc}^{*} \mathrm{mwc} *(\mathrm{ABS}(3-2))\right)\right.\right.\right.\right.$ $((\mathrm{hwc}+\mathrm{mwc}+\mathrm{lwc}) *(\mathrm{hwc}+\mathrm{mwc}+\mathrm{lwc})))$. 'hwc' indicates 'high wage category', 'mwc' indicates 'middle wage category' and 'lwc' indicates 'low wage category'. 